\title{
Kilka uwag o frazeologizmach w słownikach dwujęzycznych online
}

\author{
Some remarks on phrasemes in bilingual online dictionaries
}

\author{
Magdalena LISIECKA-CZOP \\ Uniwersytet Szczeciński/ University of Szczecin \\ E-mail: magdalena.lisiecka-czop@usz.edu.pl
}

\begin{abstract}
This paper deals with the lexicographic description of phraseologic units in online dictionaries. Bilingual electronic dictionaries are not limited by space capacity, unlike paper dictionaries. Besides they offer the possibility of searching, selecting, and complementing lexicographic data in several ways, linking to other information sources such as electronic corpora. These factors influence the format of the presentation of phrasemes and remove many problems with multiword expressions, which print dictionaries have to tackle. The discussion first involves the selection of phrasemes. It makes sense to find fixed expressions useful for foreign language learners and distinguish between the ones relevant for the active usage and those for the reception. It could be taken into account by lexicographers to lemmatise phrasemes both as headwords of their own as well as under each component, as a part of their microstructure. The second question is what is the appropriate citation form to be entered. The current lexicographic practice tends to lemmatise verbal phrases in the infinitive form, however this may be confusing because of several morphological and syntactic restrictions. Therefore it seems more adequate if verbal phrases occur in the form indicating the slots in the valency like $j d$. zieht jdn. über den Tisch. On the other hand the citation form should indicate grammatical, lexical and pragmatic variation by the means of typography and proper examples, e.g. from a corpus. Obligatory, facultative, and alternative components should be marked as well. The different lexicographic practices were discussed on the example of phrasemes with the component Tisch from bilingual German-Polish dictionaries such as Pons, Leo, Bab.la, and Glosbe as well as two phraseologic dictionaries.
\end{abstract}

Keywords: exicography, phraseography, phraseology, online dictionaries, phrasemes, lemmatization, citation form

\section{Wstęp}

Opis leksykograficzny frazeologizmów jest istotnym czynnikiem wpływającym na jakość i przydatność słownika. Stwierdzenie to odnosi się w równym stopniu do słowników drukowanych jak i do słowników elektronicznych, w tym również dostępnych online, które w ostatnich latach zdają się coraz bardziej wypierać słowniki tradycyjne.

Przyczyn zjawiska rosnącej popularności słowników internetowych jest co najmniej kilka. Ch. Möhrs i C. Müller-Spitzer wymieniają wśród nich:

1. brak ograniczeń miejsca - medium elektroniczne umożliwia pisanie artykułów hasłowych bez konieczności używania skrótów i innych technik kondensacji tekstu, typowych dla słowników drukowanych. Sprzyja to przejrzystemu, przyjaznemu dla użytkowników układowi artykułu hasłowego; 
2. dostosowanie do użytkownika - dane leksykograficzne mogą być wyszukiwane i prezentowane w różnoraki sposób, w zależności od potrzeb i preferencji użytkownika. Co więcej, liczne słowniki internetowe są z założenia słownikami interaktywnymi. Mają bowiem wbudowane moduły umożliwiające dodawanie, uzupełnianie i korektę artykułów hasłowych. Zazwyczaj jest to możliwe po akceptacji moderatora, tak aby uniknąć nadużyć. Tak więc słownik internetowy jest systemem otwartym, który podlega ciągłym modyfikacjom i aktualizacjom, podczas gdy słownik drukowany jest systemem zamkniętym, którego zawartość jest niezmienna, przynajmniej do ukazania się następnego wydania;

3. powiązanie z innymi zasobami sieciowymi - wbudowane odsyłacze i linki umożliwiają wygodne i proste poruszanie się po zasobach sieciowych (inne miejsca w tym samym słowniku, inne słowniki, tabele fleksyjne, korpusy językowe, encyklopedie) i pozyskiwanie dodatkowych informacji na temat danej jednostki leksykalnej, a także równoległą prezentację hasła w różnych słownikach i zasobach internetowych;

4. oparcie słowników na korpusach językowych - w odróżnieniu od słowników drukowanych, które bazują na przykładach skonstruowanych przez autorów lub specjalnie wyekscerpowanych na potrzeby słownika, liczne słowniki internetowe, opierają się na korpusach językowych, obejmujących statystycznie reprezentatywną, szeroką próbę autentycznych danych językowych. W przypadku słowników bilingwalnych wykorzystuje się niekiedy również korpusy równoległe. Coraz bardziej wyrafinowane metody analizy komputerowej umożliwiają wyszukiwanie jednostki, formy lub grupy leksykalnej zarówno w korpusie jak i słowniku, a także prezentację danych korpusowych obok danych leksykograficznych. (zob. Ch. Möhrs/ C. Müller-Spitzer 2012: 6 i nast., thum.: M. L.-Cz.).

Do powyższych czynników dochodzi jeszcze łatwość wyszukiwania jednostki leksykalnej - poprzez okienko wyszukiwania i możliwość wpisania fragmentu leksemu w skróconej formie, a także ze sporą tolerancją dla błędnej pisowni - albo wyszukanie hasła poprzez kliknięcie hiperlinka. Należy jeszcze wspomnieć o wygodzie użytkowania - możliwe jest korzystanie z zasobów słownikowych na urządzeniach mobilnych - smartfonach (które prawie każdy ma przy sobie), tabletach czy notebookach - wystarczy mieć tylko dostęp do sieci, choć i to nie jest warunkiem koniecznym, gdyż istnieje szereg aplikacji działających offline. Dostrzegając potencjał smartfonów, większość portali leksykograficznych udostępnia specjalne aplikacje przeznaczone na podręczne urządzenia mobilne.

Celem moich rozważań jest odpowiedź na pytanie, czy przedstawione nowe możliwości, które stwarza leksykografia elektroniczna, sprzyjają systematycznej, spójnej i przyjaznej dla użytkownika prezentacji frazeologizmów w słownikach bilingwalnych. Czy materiał frazeograficzny jest wystarczająco obszerny, czy jego odnalezienie nie sprawia kłopotów i czy opis jest informatywny? 
Analizie poddałam cztery popularne słowniki internetowe, występujące w relacji niemiecko-polskiej: PONS ${ }^{1}$, LEO $^{2}$, BAB.LA ${ }^{3}$ i GLOSBE ${ }^{4}$.

\section{Obszerność i selekcja materiału frazeologicznego}

Nawet powierzchowna analiza ilościowa słowników bilingwalnych pozwala stwierdzić, że zawierają one znacznie mniej frazeologizmów, niż słowniki frazeologiczne ${ }^{5}$. Jest to zrozumiałe i uzasadnione, ponieważ słowniki ogólne mają być reprezentatywne dla języka, którym porozumiewa się ogół użytkowników. Dlatego też szczególne zasoby leksykalne, jakimi są frazeologizmy, mogą być uwzględnione tylko w pewnym stopniu, a nie kompleksowo, jak to czynią słowniki frazeologiczne.

Na przykład popularny niemiecki słownik frazeologiczny online redensarten-index.de (RI) zawiera 28 frazeologizmów z członem Tisch:

1. bei Tisch;

2. vom Tisch sein;

3. den Tisch decken;

4. reinen Tisch machen;

5. auf dem Tisch liegen;

6. unter dem Tisch liegen;

7. unter den Tisch fallen;

8. etwas vom Tisch kriegen;

9. die Sache muss vom Tisch;

10. etwas auf den Tisch legen;

11. nicht auf den Tisch kommen;

12. sich an einen Tisch setzen;

13. etwas unter den Tisch kehren;

14. jemanden unter den Tisch trinken;

15. am runden Tisch; der runde Tisch;

16. jemanden über den Tisch ziehen;

17. etwas unter den Tisch fallen lassen;

18. über den Tisch / Ladentisch gehen;

19. zu Tisch rufen/ bitten/ gehen/ sein;

20. die Karten (offen) auf den Tisch legen;

21. (Scheine, Geld) auf den Tisch blättern;

22. am grünen Tisch; vom grünen Tisch aus;

23. alle/ beide Parteien an einen Tisch bringen;

24. (mit der Faust) auf den Tisch hauen/ schlagen;

25. etwas (einfach) vom Tisch wischen/ fegen; etwas unter den Tisch wischen/ fegen;

26. Trennung/ Scheidung von Tisch und Bett; von Tisch und Bett getrennt sein/ leben;

\footnotetext{
${ }^{1} \mathrm{http}: / /$ pl.pons.com.

${ }^{2} \mathrm{http} / / / \mathrm{www}$. leo.org/.

${ }^{3} \mathrm{http}: / /$ pl.bab.la/slownik/.

${ }^{4}$ https://pl.glosbe.com/.

${ }^{5}$ Jeśli chodzi o słowniki jednojęzyczne, proporcje mogą być inne. Np. M. Bańko stwierdza, że jednotomowe słowniki języka polskiego zawierają więcej frazeologizmów niż popularny Słownik frazeologiczny współczesnej polszczyzny Bąby i Liberka (M. Bańko 2001:153).
} 
27. Ist die Katze aus dem Haus, tanzen die Mäuse auf dem Tisch; Ist die Katz aus dem Haus, rührt sich die Maus; Wenn die Katze aus dem Haus ist, tanzen die Mäuse;

28. bei jemandem die Füße / Beine unter den Tisch strecken / stecken / stellen / haben; die Beine / Füße unter jemandes Tisch strecken / stecken / stellen / haben.

Słownik frazeologiczny niemiecko-polski online ${ }^{6}$ (FRAZ) zawiera natomiast 14 frazeologizmów:

1. da wird reiner Tisch gemacht;

2. \#jd. macht mit \#etw. reinen Tisch;

3. \#jd. trinkt \#jdn. unter den Tisch;

4. am runden Tisch;

5. am grünen Tisch;

6. bei Tisch;

7. nach Tisch;

8. vor Tisch;

9. zu Tisch;

10. von Tisch und Bett getrennt leben;

11. bar auf den Tisch des Hauses;

12. \#jd. zieht \#jdn. über den Tisch;

13. \#jd. streckt die Beine unter \#jds. Tisch;

14. \#etw. ist vom Tisch.

Podobna analiza dwujęzycznych słowników ogólnych wykazała, że niemiecko-polska wersja słownika PONS zawiera 13 frazeologizmów (ściślej 12, ponieważ pierwszy i drugi wpis dotyczy jednego, polisemicznego frazeologizmu), określanych jako "zwroty":

1. [mit etw] reinen Tisch machen fam

2. [mit etw] reinen Tisch machen fam

3. unter den Tisch fallen fam

4. etw unter den Tisch fallen lassen fam

5. etw ist vom Tisch fam

6. jdn über den Tisch ziehen fam

7. am runden Tisch

8. vom grünen Tisch aus

9. mit der Faust auf den Tisch hauen

10. die Karten offen auf den Tisch legen

11. sich an den gedeckten Tisch setzen

12. jdn unter den Tisch trinken fam

13. Einwände vom Tisch wischen
- uporządkować [oder uregulować] [coś];

- zrobić [z czymś] porządek;

- nie zostać uwzględnionym;

- pominąć coś;

- to już jest załatwione fam;

- nabrać kogoś fam;

- przy okrągłym stole;

- zza biurka;

- walnąć pięścią w stół fam;

- kłaść [perf położyć] karty na stół;

- przyjść na gotowe;

- okazać się silniejszym w piciu;

- lekceważyć zarzuty.

Ponadto jedno z połączeń wielowyrazowych, odnotowanych również przez RI - 'den Tisch decken' - 'nakrywać do stołu', jest właściwie kolokacją, gdyż nie wykazuje metaforyczności znaczenia i słusznie zostało umieszczone w pierwszej, głównej, części artykułu hasłowego.

\footnotetext{
${ }^{6}$ http://frazeologizmy.univ.szczecin.pl/
} 
Słownik niemiecko-polski LEO podaje w artykule hasłowym Tisch jedną kolokację oraz cztery frazeologizmy czasownikowe (w części hasła zatytułowanej 'Verben'), przy czym również wśród tych wpisów znajdują się frazeologizmy polisemiczne (3 i 4) oraz warianty frazeologiczne (2 i 5):

1. sprzątać ze stołu perfektiv: sprzątnąc - den Tisch abdecken;

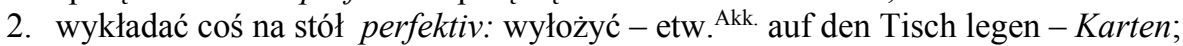

3. zignorować coś - etw. Akk. (einfach) vom Tisch fegen [fig.];

4. odrzucić coś bez namysłu - etw. Akk. (einfach) vom Tisch fegen [fig.];

5. wykładać karty na stół [fig.] perfektiv: wyłożyć - die Karten (offen) auf den Tisch legen [fig.].

Słownik LEO podaje również jedno przysłowie w części hasła zatytułowanej 'Phrasen':

myszy tańcują, kiedy kota nie czują - ist die Katze aus dem Haus, tanzen die Mäuse auf dem Tisch.

Jeszcze mniej zwrotów podaje słownik GLOSBE, bo tylko dwie kolokacje, przy czym zwroty nie są częścią mikrostruktury artykułu hasłowego, lecz występują jako oddzielne hasła:

1. den Tisch decken

- nakryć do stołu;

2. sich an den Tisch setzen

- siadać do stołu;

dwa związki frazeologiczne:

1. runder/ Runder Tisch

2. Tisch und Bett

- okrągły stół;

- małżeństwo;

oraz jedno przysłowie:

Wenn die Katze aus dem Hause ist, tanzen die Mäuse (auf dem Tisch) - Myszy doka-

zują, gdy kota nie czują; Gdy kota nie ma, myszy harcują.

Inne frazeologizmy z członem Tisch obecne są w korpusie równoległym wyświetlanym pod opisem leksykograficznym hasła w słowniku GLOSBE, ale nie są obecne w samym opisie, np.:

Die Landwirtschaft sieht kinderleicht aus, wenn man sie vom grünen Tisch aus betreibt und die Getreidefelder meilenweit weg sind.
Uprawianie ziemi wydaje się dziecinnie proste, gdy siedzisz za biurkiem, a od najbliższego pola dzieli cię szmat drogi

W słowniku BAB.LA nie występują $\mathrm{w}$ opisie hasła Tisch żadne jednostki frazeologiczne, natomiast wpisując $\mathrm{w}$ okienko wyszukiwania frazeologizmy $\mathrm{z}$ tym rzeczownikiem, odnajdziemy trzy opisy:

1. den Tisch decken

2. runder Tisch

3. vom grünen Tisch aus
- nakrywać do stołu, nakryć do stołu;

- okrągły stół;

- zza biurka, biurokratycznie.

Liczne frazeologizmy można natomiast odnaleźć w korpusie równoległym BAB.LA, towarzyszącym hasłu Tisch, np.: 
Aber ich möchte kurz auf eine gegenteilige Sache zu sprechen kommen und sozusagen reinen Tisch machen
Ale teraz chcę obrócić to do góry nogami, wyłożyć kawę na ławę i oczyścić atmosferę.

Użytkownik portalu jest jednak w konfrontacji z przykładami pozostawiony własnej dedukcji, autorzy słownika nie dostarczają mu żadnych wskazówek ani informacji dotyczących frazeologicznego użycia tej jednostki wielowyrazowej.

Skoro słowniki bilingwalne zawierają mniej frazeologizmów niż słowniki frazeologiczne czy korpusy językowe, to można sobie postawić pytanie, według jakich kryteriów należy dokonać wyboru tych jednostek frazeologicznych?

Autorzy starszych słowników dwujęzycznych zwykle kierowali się przy selekcji materiału frazeologicznego własną kompetencją językową i intuicją. J. Czochralski i K.D. Ludwig, twórcy Stownika frazeologicznego niemiecko-polskiego, uzasadniają to w następujący sposób:

Staraliśmy się w miarę możliwości uwzględnić te frazeologizmy, które aktualnie należą do powszechnie stosowanych frazemów i tym samym odpowiadają współczesnemu uzusowi językowemu i językowi ogólnemu (J. Czochralski/ K.D. Ludwig 1996: 175, thum.: M. L.-Cz.).

przy czym przyznają, że współczesny uzus jest dość względnym punktem odniesienia, zależnym również od przynależności pokoleniowej.

Wybór frazeologizmów w słowniku dwujęzycznym uzależniony jest również od celu - czy słownik ma służyć przede wszystkim recepcji - wtedy należałoby uwzględnić jak największą liczbę frazeologicznych jednostek leksykalnych, czy też produkcji językowej - w takim przypadku należałoby uwzględnić te frazeologizmy, które użytkownik powinien czynnie opanować, aby móc sprawnie komunikować się w języku obcym. Wtedy też ich opis leksykograficzny powinien być dostosowany do wymogów aktywnego użycia (por. D. Dobrovol'skij 1999: 164 i nast.).

Ponieważ głównymi obszarami zastosowania ogólnych słowników bilingwalnych jest translacja i akwizycja języka, pewnym punktem odniesienia mogłoby stać się tzw. minimum, czy optimum frazeologiczne. O stworzenie takiego optimum dla osób uczących się języka niemieckiego jako obcego pokusili się E. Hallsteinsdóttir/ M. Šajankova/ U. Quasthoff (2006).

Przeprowadzili oni dwa badania - frekwencyjną analizę 1112 frazeologizmów, występujących w słownikach Deutsch als Fremdsprache (jednojęzycznych, przeznaczonych dla osób uczących się niemieckiego), w niemieckim korpusie „Deutscher Wortschatz ${ }^{\text {“8 }}$ oraz ankietę wśród rodzimych użytkowników języka niemieckiego na temat znajomości tychże frazeologizmów. Pomijając pewne słabości tej metody - np.

7 ,Wir haben uns bemüht, möglichst die Phraseologismen zu verzeichnen, die zu den heute allgemein verwendeten Phrasemen gehören und somit weitgehend dem gegenwärtigen Sprachgebrauch und der Allgemeinsprache entsprechen.“

${ }^{8} \mathrm{http}: / /$ wortschatz.uni-leipzig.de/de. 
oparcie na korpusie języka pisanego i statystycznie nie do końca reprezentatywny dobór osób do badania ankietowego ${ }^{9}$ - korelacja tych dwóch badań daje wgląd w relewancję komunikacyjną poszczególnych frazeologizmów.

E. Hallsteinsdóttir/ M. Šajankova/ U. Quasthoff wyodrębnili grupę 143 frazeologizmów, które zarówno często występują w korpusie (ponad 500 przykładów), jak i są wskazywane przez ponad $75 \%$ ankietowanych jako element ich słownictwa aktywnego. Wśród tych frazeologizmów znalazły się dwa z komponentem Tisch, notowane przez badane przeze mnie słowniki:

- $\quad$ jn über den Tisch ziehen (miejsce 71) oraz

- unter den Tisch fallen (miejsce 87).

Frazeologizm jn über den Tisch ziehen jest obecny w słownikach frazeologicznych RI i FRAZ, ale tylko w jednym dwujęzycznym słowniku ogólnym online - PONS.

Drugi frazeologizm, unter den Tisch fallen, jest natomiast zlematyzowany tylko w słownikach RI i PONS. Przy doborze jednostek frazeograficznych w analizowanych słownikach należałoby więc jednak w większym zakresie uwzględnić kryterium ich przydatności dla osób uczących się języka, zarówno w rozumieniu jak i produkcji tekstów.

\section{Miejsce i forma prezentacji frazeologizmów}

\subsection{Umiejscowienie frazeologizmów w słowniku}

Sposób prezentacji hasła w słowniku elektronicznym znacznie różni się od artykułu w słowniku drukowanym. Przede wszystkim hasła mają budowę tabelaryczną albo modułową, podczas gdy w tradycyjnym słowniku jest to forma tekstowa składająca się z segmentów. Struktura tabelaryczna jest przejrzysta i umożliwia równoległe porównanie elementów w obu językach.

W słownikach drukowanych frazeologizmy mogą występować jako elementy mikrostruktury lub oddzielne hasła (ma to miejsce w przypadku słowników frazeologicznych, rzadziej w słownikach ogólnych).

Zagadnienie miejsca frazeologizmów w makro- i mikrostrukturze słownika drukowanego jest szeroko dyskutowane w literaturze frazeograficznej. Wiele kontrowersji wzbudza szczególnie kwestia wyodrębnienia frazeologizmów jako osobnych haseł lub przyporządkowania ich do artykułów hasłowych dotyczących jednego z ich członów. W tym drugim przypadku do rozstrzygnięcia pozostaje kwestia kryterium wyboru nadrzędnego członu - czy ma być to pierwszy element, czy pierwszy rzeczownik (lub inny wyraz autosemantyczny), a może człon najsilniej motywujący dany związek frazeologiczny? Czy frazeologizm powinien być hasłowany tylko raz w słowniku, czy wymaga odsyłaczy pod pozostałymi komponentami, czy wielokrotnego hasłowania i jak skorelować między sobą opisy pochodzące od różnych autorów? (por. m.in.

\footnotetext{
${ }^{9} \mathrm{~W}$ ankiecie rozesłanej drogą mailową na niemieckie uniwersytety, wzięło udział 101 respondentów, głównie studentów i absolwentów tych uczelni. Większość (64) stanowiły osoby młode, które nie ukończyły 30 lat (por. E. Hallsteinsdóttir/ M. Šajankova/ U. Quasthoff, 2006).
} 
M. Bańko 2001: 170 i nast., L. Martín 2001: 91 i nast., M. Bielińska 2007: 319 i nast., G. Harras/ K. Proost 2007: 281 i nast., K. Węgrzynek 2007: 89 i. nast.).

W słownikach elektronicznych, w których z założenia nie występuje ograniczenie miejsca, możliwe jest wyszukanie frazeologizmu jako całej jednostki, ale także poprzez wpisanie w okienko wyszukiwania jednego z jego elementów, np. po wpisaniu wyrazu Tisch powinno pojawić się hasło, którego częścią są również stałe frazy z tym wyrazem. Jednak nie każdy słownik internetowy stwarza taką możliwość, np. w portalu BAB.LA należy wpisać całą frazę, aby uzyskać dostęp do jej opisu. Jest to rozwiązanie o tyle problematyczne, że większość użytkowników jest przyzwyczajona do poszukiwania frazeologizmu w mikrostrukturze jego głównego członu - tak jak się to dzieje w większości słowników drukowanych. Ponadto samodzielne zrekonstruowanie formy podstawowej związku frazeologicznego również może sprawiać użytkownikowi trudności.

Optymalnym rozwiązaniem wydaje się być - w przypadku słowników elektronicznych - wielokrotne hasłowanie frazeologizmu: jako całej frazy i jej elementów składowych, przynajmniej wszystkich autosemantycznych. Rozstrzygnięcie takie problematyczne w słownikach drukowanych z uwagi na koszty i oszczędność miejsca - w słownikach online nie nastręcza większych problemów technicznych, a znacznie usprawniłoby wyszukiwanie pożądanej informacji leksykograficznej.

\subsection{Forma podstawowa frazeologizmu}

Jak wspomniano, słowniki bilingwalne mają za zadanie służyć użytkownikom pomocą przy rozumieniu i produkcji tekstów w innym języku. Dlatego też forma prezentacji jednostek leksykalnych, w tym frazeologizmów, powinna uwzględniać ich adekwatne i odpowiednie do sytuacji i rodzaju tekstu użycie. Chodzi o wybór reprezentatywnego wariantu leksykalnego (lub wariantów) i formy gramatycznej, która odzwierciedla schemat składniowy, a więc walencję, zmienne i ewentualne restrykcje użycia (por. M. Lisiecka-Czop/ D. Misiek 2012: 136).

We frazeografii przyjęło się, że forma gramatyczna związku frazeologicznego odpowiada formie stosowanej dla leksemów jednowyrazowych. Tak więc:

1. dla frazeologizmów czasownikowych są to formy bezokolicznikowe;

2. dla frazeologizmów rzeczownikowych - formy mianownika liczby pojedynczej;

3. dla przymiotnika - forma w stopniu równym, liczbie pojedynczej, bez końcówki fleksyjnej (por. V. Schnorr 1991: 2813).

$\mathrm{W}$ takiej formie prezentowane są frazeologizmy w większości badanych słowników online, zarówno we frazeologicznych, jak i ogólnych bilingwalnych. Choć jest to powszechnie przyjęta praktyka, pewne wątpliwości może budzić prezentacja frazeologizmów czasownikowych, z uwagi na często spotykane restrykcje morfosyntaktyczne (zob. G. Harras/ K. Proost 2007: 285 i nast.). Dlatego też np. J. Czochralski / K.D. Ludwig postulują, aby w przypadku frazeologizmów z takimi restrykcjami odstąpić od formy bezokolicznikowej na rzecz formy fleksyjnej, np.: jmdm. fällt die Decke auf den Kopf (J. Czochralski/ K.D. Ludwig 1999: 183 i nast.). 
Zróżnicowanie form podstawowych frazeologizmów czasownikowych w obrębie jednego słownika stwarza jednak wrażenie pewniej niekonsekwencji, dlatego też lepszym rozwiązaniem wydaje się być przyjęcie zasady, że frazeologizmy czasownikowe są prezentowane w formie fleksyjnej. Przyjrzyjmy się przykładom ze słowników:

Przykład 1:

RI: $\quad$ jemanden über den Tisch ziehen

PONS: $\quad$ jdn über den Tisch ziehen

FRAZ: $\quad$ \#jd. zieht \#jdn. über den Tisch

$\mathrm{W}$ przypadku tego frazeologizmu restrykcjom podlega zarówno dopełnienie jak i podmiot - obydwa muszą być wyrażone rzeczownikami osobowym (lub zaimkami zastępującym je). Forma bezokolicznikowa ukazuje to ograniczenie tylko w odniesieniu do dopełnienia, co potencjalnie może prowadzić do błędnego stosowania frazeologizmu.

\section{Przykład 2:}

$\mathrm{Z}$ podobną sytuacją mamy do czynienia $\mathrm{w}$ analizowanych słownikach $\mathrm{w}$ odniesieniu do frazeologizmu vom Tisch sein:

RI: vom Tisch sein

FRAZ: \#etw. ist vom Tisch

PONS: $\quad$ etw. ist vom Tisch (poln. to już jest załatwione fam)

Restrykcja dotyczy w tym przypadku podmiotu, który jest nieosobowy. Jeśli pozostawimy zwyczajowo przyjętą formę bezokolicznikową, bez zmiennej mianownikowej 'etwas', użytkownik zostanie pozbawiony istotnej informacji na temat możliwości konkretnego użycia frazeologizmu. Zapewne dlatego też autor hasła w słowniku PONS zdecydował się na odstępstwo od przyjętej formy bezokolicznikowej na rzecz formy fleksyjnej. Jednak podając ekwiwalent $\mathrm{w}$ języku polskim dopuścił się niekonsekwencji - zamiast adekwatnej formy fleksyjnej 'coś już jest załatwione', mamy konkretny przykład użycia, w którym zmienna została zaktualizowana konkretnym zaimkiem.

Przy tej okazji warto zwrócić uwagę na jeszcze jeden problematyczny aspekt zapisu frazeologizmu. O ile zmienne 'jemand'/'jemandem', jemanden' będące symbolicznym wypełnieniem miejsca podmiotu lub dopełnienia osobowego dostarczają również informacji na temat formy gramatycznej, o tyle komponent 'etwas' symbolizujący rzeczownik nieosobowy, takiej informacji jednak nie zawiera. Ciekawe rozwiązanie proponuje w takim przypadku słownik LEO:

Przykład 3:

RI: etwas (einfach) vom Tisch wischen/ fegen; etwas unter den Tisch wischen/ fegen

PONS: Einwände vom Tisch wischen - lekceważyć zarzuty

LEO: $\quad$ zignorować coś - etw. Akk. (einfach) vom Tisch fegen [fig.] odrzucić coś bez namysłu - etw. Akk. (einfach) vom Tisch fegen [fig.] 
W słowniku LEO zmienna zawiera marker gramatyczny (Akk.), oznaczający dopełnienie w bierniku. Przedstawienie tego frazeologizmu w słowniku PONS może natomiast wprowadzić użytkownika w błąd. Miejsce zmiennej zostało wypełnione konkretnym rzeczownikiem (Einwände), co jest nadmierną restrykcją i sugeruje, iż mamy do czynienia ze komponentem stałym, niezmiennym, a zarazem jedyną poprawną formą danego frazeologizmu, a nie z konkretnym przykładem użycia.

Restrykcje użycia mogą dotyczyć aspektów morfosynktaktycznych, semantycznych ale również pragmatycznych, na przykład przynależności frazeologizmu do określonego stylu funkcjonalnego lub dziedziny specjalistycznej. Restrykcje takie z reguły oznaczane są przez przez kwalifikatory (np. fam., pot.) lub glosy leksykograficzne.

Równie istotną kwestią, co restrykcje użycia, jest wariantywność frazeologizmów, a więc zapis elementów alternatywnych i fakultatywnych. $Z$ takim przypadkiem mamy do czynienia w przykładzie 3 . Elementami alternatywnymi są czasowniki wischen und fegen, a elementem fakultatywnym przysłówek einfach. Ponadto słownik RI podaje jeszcze dwa alternatywne warianty przyimkowe (vom Tisch i unter den Ti$s c h$ ). Nie wszystkie warianty frazeologizmu zostały uwzględnione w słownikach dwujęzycznych PONS i LEO.

Ponieważ w słowniku online zwykle nie ma wydzielonych objaśnień dla użytkownika, powinien to być przejrzysty zapis pozwalający użytkownikowi intuicyjnie i jednoznacznie odróżnić elementy obligatoryjne od fakultatywnych oraz alternatywnych. Autorzy mają do dyspozycji szereg środków typograficznych: nawiasy do oznaczania elementów fakultatywnych, ukośniki - do alternatywnych, a także inny krój czcionki np. do oznaczania zmiennych sygnalizujących walencję zewnętrzną frazeologizmu (por. również M. Bielińska 2007: 321). Typograficznie należy również wyodrębnić element metajęzykowe, takie jak kwalifikatory czy uzupełnienia.

Niektóre frazeologizmy wykazują dużą wariantywność, dlatego też tradycyjny, skondensowany sposób zapisu byłby nieprzejrzysty. Dzięki temu, że autor hasła w słowniku elektronicznym nie jest ograniczony miejscem, tak jak to się dzieje w przypadku słowników drukowanych, możliwe jest nawet rozpisanie dwóch (lub potencjalnie kilku) wariantów haseł obok siebie, jak to czynią słowniki RI I FRAZ:

Przykład 4:

RI: bei jemandem die Füße / Beine unter den Tisch strecken / stecken / stellen / haben; die Beine / Füße unter jemandes Tisch strecken / stecken / stellen / haben;

FRAZ: \#jd. streckt die Beine unter \#jds. Tisch; \#jd. streckt die Füße unter \#jds. Tisch.

Jednak dopiero lektura załączonych przykładów korpusowych pozwala użytkownikowi zorientować się, że ten związek frazeologiczny zazwyczaj występuje w jednym, określonym wariancie składniowym, a mianowicie zdania okolicznikowego czasu, rozpoczynającego się od spójnika solange:

"Solange du die Füße unter unseren Tisch stellst, machst du, was wir sagen"; "'Gerecht und streng', so erinnert er sich an seinen Vater. 'Solange du die Füße unter meinen Tisch steckst', sagte der eines Tages zu ihm, 'wird gemacht, was ich sage.' Da zog der Sohn die Füße unter dem Tisch hervor. Er verließ die Schule mit 15 Jahren nach der mittleren 
Reife und wurde - mit Zustimmung der Eltern - Verwaltungskandidat im Kreis Heilbronn"; "Solange deine Füße unter meinem Tisch sind, gehst du so nicht auf die Straße!"; "Wenn man einem alles diktiert wie 'Was auf dem Tisch kommt, wird gegessen' oder 'Solange du deine Beine unter meinen Tisch streckst, habe ich hier das Sagen' werden kaum mündige Bürger heranwachsen" [RI].

Dowodzi to, jak ważny jest dobór jakościowy i ilościowy cytatów lub przykładów, zwłaszcza dla aktywnego opanowania frazeologizmu.

\section{Podsumowanie}

Przedstawiona analiza wybranych przykładów frazeologizmów ze słowników online pozwala sformułować kilka istotnych postulatów dotyczących praktyki frazeograficznej w leksykografii elektronicznej:

1. Dobór frazeologizmów w słownikach powinien uwzględniać ich relewancję komunikacyjną - to znaczy słowniki powinny zawierać związki frazeologiczne o wysokiej frekwencji występowania zarówno w korpusach językowych jak i w uzusie.

2. Wobec braku ograniczeń miejsca należy konsekwentnie dążyć do możliwości wyszukiwania frazeologizmów zarówno jako całych haseł jak i według ich poszczególnych elementów składowych, a w słownikach frazeologicznych również według ich właściwości (np. frazeologizmy czasownikowe, frazeologizmy potoczne, frazeologizmy z zakresu języka prawa itp.).

3. Forma prezentacji frazeologizmu powinna odzwierciedlać jej zrekonstruowany schemat składniowy, a więc walencję, zmienne i ewentualne restrykcje użycia. Postulat ten dotyczy również słowników drukowanych (por. M. Lisiecka-Czop/ D. Misiek 2012: 136). W przypadku słowników internetowych dobrym pomysłem wydaje się powiązanie informacji leksykograficznych z przykładami użycia, np. z korpusów językowych - bądź przez wybór reprezentatywnych przykładów w mikrostrukturze hasła, bądź przez odsyłacze do powiązanych zasobów, np. do korpusów równoległych w przypadku słowników dwujęzycznych.

4. Ekwiwalenty w słownikach bilingwalnych powinny odpowiadać hasłom nie tylko pod względem semantycznym czy stylistycznym, ale też i formalnym, tj. wybrana forma podstawowa musi być taka sama dla hasła i ekwiwalentu.

5. Zapis frazeologizmów w słowniku powinien odzwierciedlić ich wariantywność gramatyczną i leksykalną. Wobec braku eksplicytnych wskazówek dla użytkownika należy dążyć do przejrzystego i jednoznacznego wyróżnienia komponentów obligatoryjnych, fakultatywnych i alterna-tywnych.

\section{Bibliografia}

Bańko, M. (2001), Z pogranicza leksykografii i językoznawstwa. Warszawa.

Bielińska, M. (2007), Propozycje kryteriów ewaluacji opisu leksykograficznego frazeologizmów, (w:) W. Chlebda (red.), Frazeologia a językowe obrazy świata przełomu wieków. Opole, 317-324. 
Czochralski, J.A./ K.D. Ludwig (1996), Zur Arbeit an einem phraseologischen Wörterbuch Deutsch-Polnisch. Ein Werkstattbericht, (w:) H.E. Wiegand (red.), Studien zur zweisprachigen Lexikographie mit Deutsch III, Hildesheim et al., 171-187.

Dobrovol'skij, D. (1999), Phraseologische Wörterbücher Deutsch-Russisch und Russisch-Deutsch, (w:) H.E. Wiegand (red.), Studien zur zweisprachigen Lexikographie mit Deutsch IV, Hildesheim etc., 141-175.

Hallsteinsdóttir, E./ M. Šajankova/ U. Quasthoff (2006), Phraseologisches Optimum für Deutsch als Fremdsprache. Ein Vorschlag auf der Basis von Frequenz- und Geläufigkeitsuntersuchungen, (w:) „Linguistik online” 27, 2/06, (URL http://www.linguistik-online.de/27_06/hallsteinsdottir_et_al.html). [Pobrano 10.07.2017].

Harras, G./ K. Proost (2005), The Lemmatisation of Idioms, (w:) H. Gottlieb/ J.E. Mogensen/ A. Zettersten (red.), Symposium on Lexicography. Proceedings of the Eleventh International Symposium on Lexicography May 2-4, 2002 at the University of Copenhagen (Lexicographica Series Maior 115), 277-291.

Lisiecka-Czop, M./ D. Misiek (2012), Formy prezentacji frazeologizmów w słownikach Pons i Partner, (w:) R. Lipczuk/ M. Lisiecka-Czop/ A. Sulikowska (red.), Frazeologizmy w słownikach niemiecko-polskich i polsko-niemieckich na przykładzie Pons Duży Słownik i Langenscheidt Słownik Partner, Szczecin. 107-139.

Martín, L. (2001), Phraseologie im zweisprachigen Wörterbuch Deutsch-Spanisch. Frankfurt a. M.

Möhrs, Ch./ C. Müller-Spitzer (2012), Elektronische Lexikografie. Tübingen.

Schnorr, V. (1991), Problems of Lemmatization in the Bilingual Dictionary, (w:) F.J. Hausmann etc. (red.), Wörterbücher. Dictionaries. Ein internationales Handbuch zur Lexikographie (Handbücher zur Sprach- und Kommunikationswissenschaft 5.3). Berlin et al., 2813-2817.

Węgrzynek, K. (2007), Związki frazeologiczne w Wielkim słowniku języka polskiego, (w:) P. Żmigrodzki/ R. Przybylska (red.), Nowe studia leksykograficzne, t. 2, Kraków, 87-100.

\section{Słowniki online}

[BAB.LA]: Stownik online w 28 językach. Wszystko o językach i ttumaczeniach: Koniugacja, Zwroty, Życie za granica i o wiele więcej (Oxford University Press), (URL http://pl.bab.la/slownik/). [Pobrano 10.07.2017].

[FRAZ]: Niemiecko-Polski Stownik Frazeologizmów on-line. Phraseologisches Online-Wörterbuch Deutsch-Polnisch (Uniwersytet Szczeciński), (URL http://frazeologizmy.univ.szczecin.pl/). [Pobrano 10.07.2017].

[GLOSBE]: Glosbe - wielojęzyczny stownik online (Glosbe s.j.), (URL https://pl.glosbe.com/). [Pobrano 10.07.2017].

[LEO]: LEOs Wörterbücher (LEO GmbH), (URL http://www.leo.org/). [Pobrano 10.07.2017].

[PONS]: Słownik internetowy PONS (PONS GmbH), (URL http://pl.pons.com). [Pobrano 10.07.2017].

[RI]: Redensarten-Index. Wörterbuch für Redensarten, Redewendungen, idiomatische Ausdrücke und feste Wortverbindungen (Peter Udem), (URL https://www.redensarten-index.de). [Pobrano 10.07.2017]. 